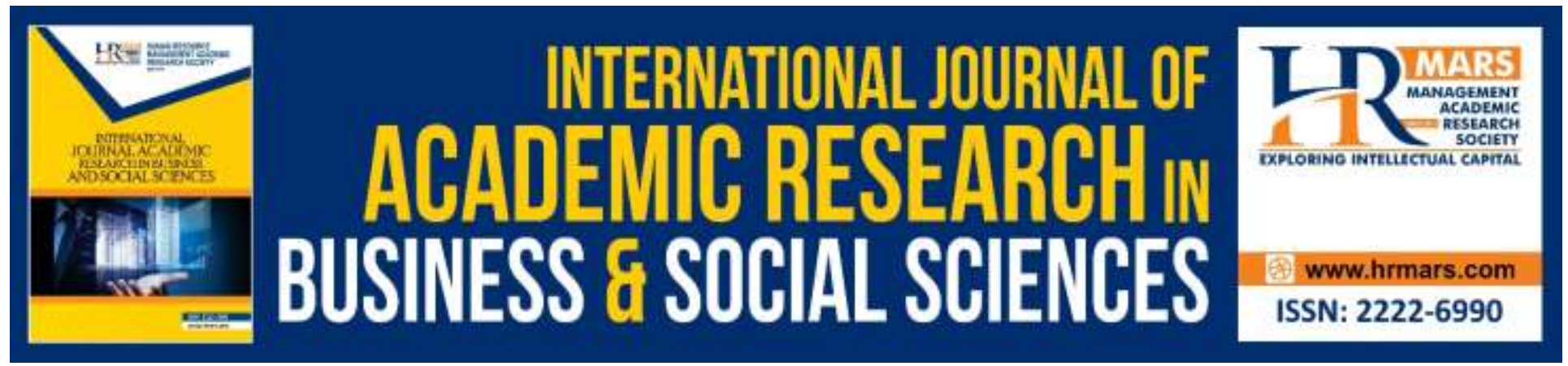

\title{
Alternative Financing for Higher Education Students: Conceptual and Empirical Issues
}

\author{
Mohd Faizal Basri, Azila Abdul Razak, Mohd Yahya Mohd Hussin, Fidlizan \\ Muhammad
}

To Link this Article: http://dx.doi.org/10.6007/IJARBSS/v9-i10/6828

DOI: 10.6007/IJARBSS/v9-i10/6828

Received: 12 Sept 2019, Revised: 28 Sept 2019, Accepted: 03 Oct 2019

Published Online: 29 Oct 2019

In-Text Citation: (Basri et al., 2019)

To Cite this Article: Basri, M. F., Razak, A. A., Hussin, M. Y. M., \& Muhammad, F. (2019). Alternative Financing for Higher Education Students: Conceptual and Empirical Issues. International Journal of Academic Research in Business and Social Sciences, 9(10), 394-405.

Copyright: (C) 2019 The Author(s)

Published by Human Resource Management Academic Research Society (www.hrmars.com)

This article is published under the Creative Commons Attribution (CC BY 4.0) license. Anyone may reproduce, distribute, translate and create derivative works of this article (for both commercial and non-commercial purposes), subject to full attribution to the original publication and authors. The full terms of this license may be seen

at: http://creativecommons.org/licences/by/4.0/legalcode

$$
\text { Vol. 9, No. 10, 2019, Pg. } 394 \text { - } 405
$$

Full Terms \& Conditions of access and use can be found at http://hrmars.com/index.php/pages/detail/publication-ethics 


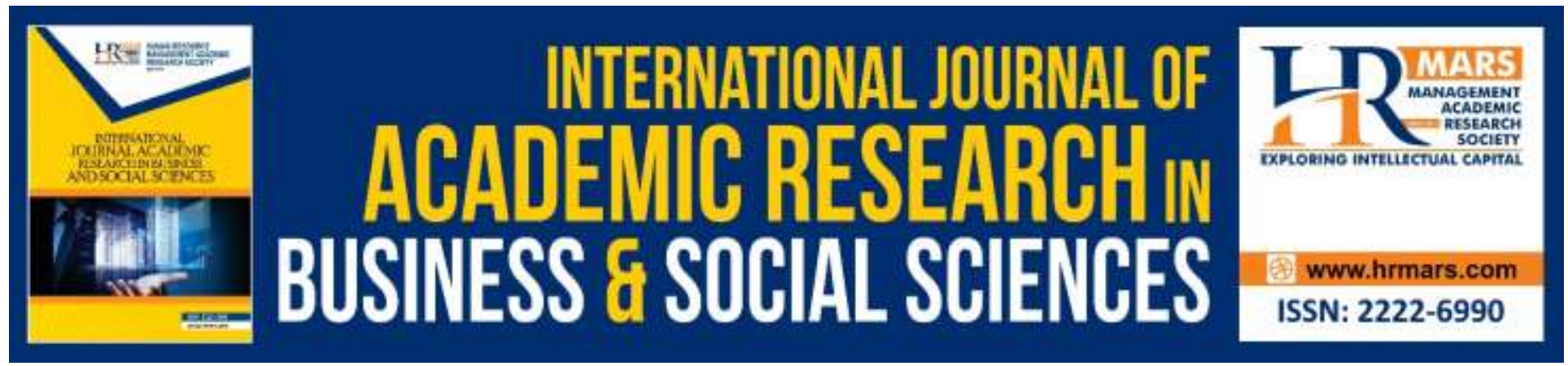

\title{
Alternative Financing for Higher Education Students: Conceptual and Empirical Issues
}

\author{
Mohd Faizal Basri, Azila Abdul Razak, Mohd Yahya Mohd Hussin, \\ Fidlizan Muhammad \\ Faculty of Management and Economics, Universiti Pendidikan Sultan Idris, Malaysia
}

\begin{abstract}
The study is expected to identify the funding mechanisms that are being used around the world with the aspiration to gather the best solutions or alternative to the existing available systems for financing of higher education in Malaysia. The intention is to improve the current system with potentially the introduction of possible alternative from waqf concept or the modern financial technology solutions such as crowdsourcing. The significance of the study will provide new sources of financing with the intention to reduce the burden of PTPTN, and not to forget the most important aspect which is to encourage students to further their studies in higher learning institutions.
\end{abstract}

Keywords: Student Loan, Education, Alternative Financing, Waqf, Crowdfunding, Crowdsourcing, PTPTN

\section{Introduction}

Higher education believed to be very beneficial to young adults especially in a developing country like Malaysia. Among the benefits including financial security, better job opportunity, and comfortable lifestyle. However, the cost of university education is on the rise in recent years with an average of RM38,000 per year (Mustafa, 2017). In an ideal world, it would be good if higher education is available for free, where the funds mostly come from taxation or charitable organisations just like some countries in the Nordic (Gibbons, 2016). However, according to Heller and Callender (2013), the nature of financing of higher education across the world is experiencing major shakeup, where many countries are less relying on traditional sources such as from taxpayers through government subsidies to students must pay on their own.

In Malaysia, the majority who are unable to secure scholarships need to seek other sources of funds, especially from education loan provider namely the Perbadanan Tabung Pendidikan Tinggi Nasional (PTPTN). Nevertheless, the recent issues faced by PTPTN including problems in the collection, and delay in disbursement may indicate that alternative to higher education financing must be in place to support the institution (Azizi, 2017; Bernama, 2017; The Star, 2017). The study 
will go through relevant secondary sources with the aspirations to explore the alternatives of education financing from different countries globally.

Previous studies mostly focus solely on the solutions to PTPTN problem. Therefore, this paper trying to fill the gap by assessing other plausible solutions to finance higher education students in Malaysia. This paper focuses on the assessment of the best practices around the world and offer the options to be applied here in Malaysia.

\section{Malaysian Higher Education}

Malaysian government spend significant amount of money in education and health (Abdul Jabbar and Selvaratnam, 2017). In October 2011, the Ministry of Education launched a comprehensive review of the education system in Malaysia in order to develop a new National Education Blueprint. The decision was made in the context of raising international education standards, the Government's aspiration of better preparing Malaysia's children for the needs of the 21st century, and increased public and parental expectations of education policy. The result is a Malaysia Education Blueprint that evaluates the performance of current Malaysia's education system with considerations of historical starting points against international benchmarks.

Fixture 1: Malaysian government expenditure on education (\%)

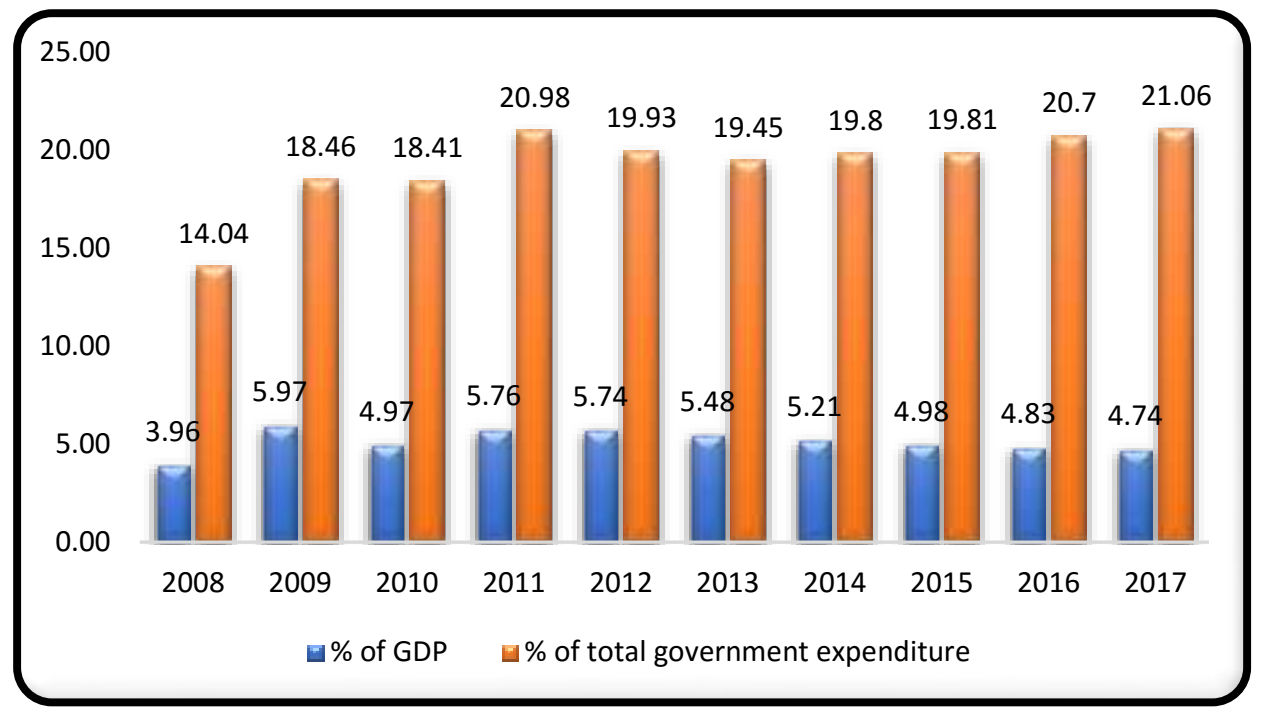

Source: UNESCO Institute for Statistics

Malaysian government spending on education has remained stagnant since 2011 until 2017 around the rate of $20 \%$ of total government expenditure. Based on Fixture 1, the only significant jump happened in 2009 with an increment of $4 \%$ from the previous year. In terms of government spending on education as per GDP, the ratio also quite stationary at the rate between $4 \%$ to $6 \%$. This figure indicates that Malaysian's government expenditure on education as percentage of GDP was the highest as compared to Singapore and Thailand (Phoong et al., 2018). Phoong et al. 
(2018) further reported that in spite of the bigger spending on education as compared to the neighbouring countries, Malaysia's return on investment ranks only 44th out of 50 countries. The education performance also lags behind other countries with similar or lower levels of expenditure on education such as Singapore and Thailand. This indicates that Malaysia has yet to be efficient to its expenditure on education

Fixture 2: Gross enrolment rate for tertiary education (\%)

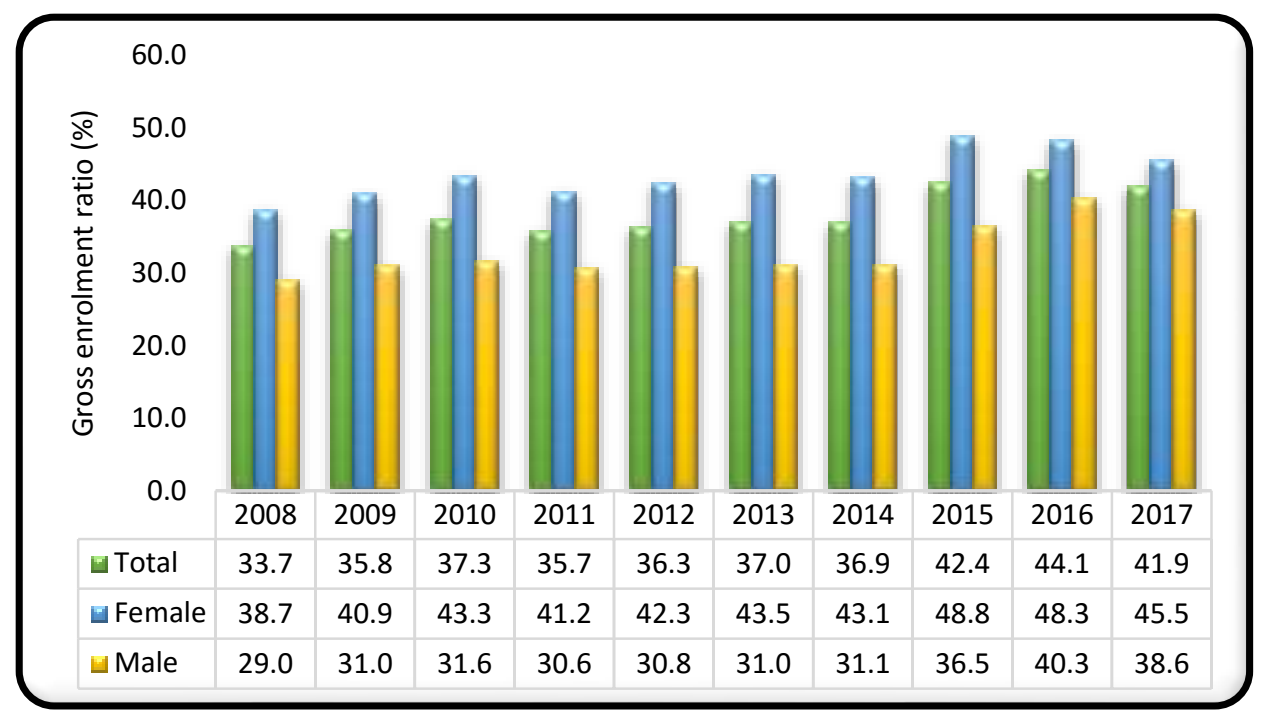

Source: UNESCO Institute for Statistics

According to Fixture 2, female has higher gross enrolment ratio as compared to male from 2008 to 2017. The highest point was recorded in 2015 for female with $48.8 \%$ while for male, it was noted in 2016 at $40.3 \%$. The numbers keep on decreasing from 2016 and 2017 for both male and female. According to Da (2012), the broadening gender gap, and specifically the disproportion of males to females in higher education, is not only about access and equity to higher education, but more critically if left unattended, have vast social and economic implications. With the government focus on Technical and Vocational Education and Training (TVET) in recent years, expectantly the number of male enrolments to higher education will grow in the near future.

Meanwhile, Wan (2017) suggested that over-representation of female students is only a problem in public universities. Additionally, over-representation of female students is found at all levels of study except doctorate in public and private universities, and Bachelor's degree in private universities. Furthermore, over-representation of female students is found in all fields of study except engineering, manufacturing and construction. 


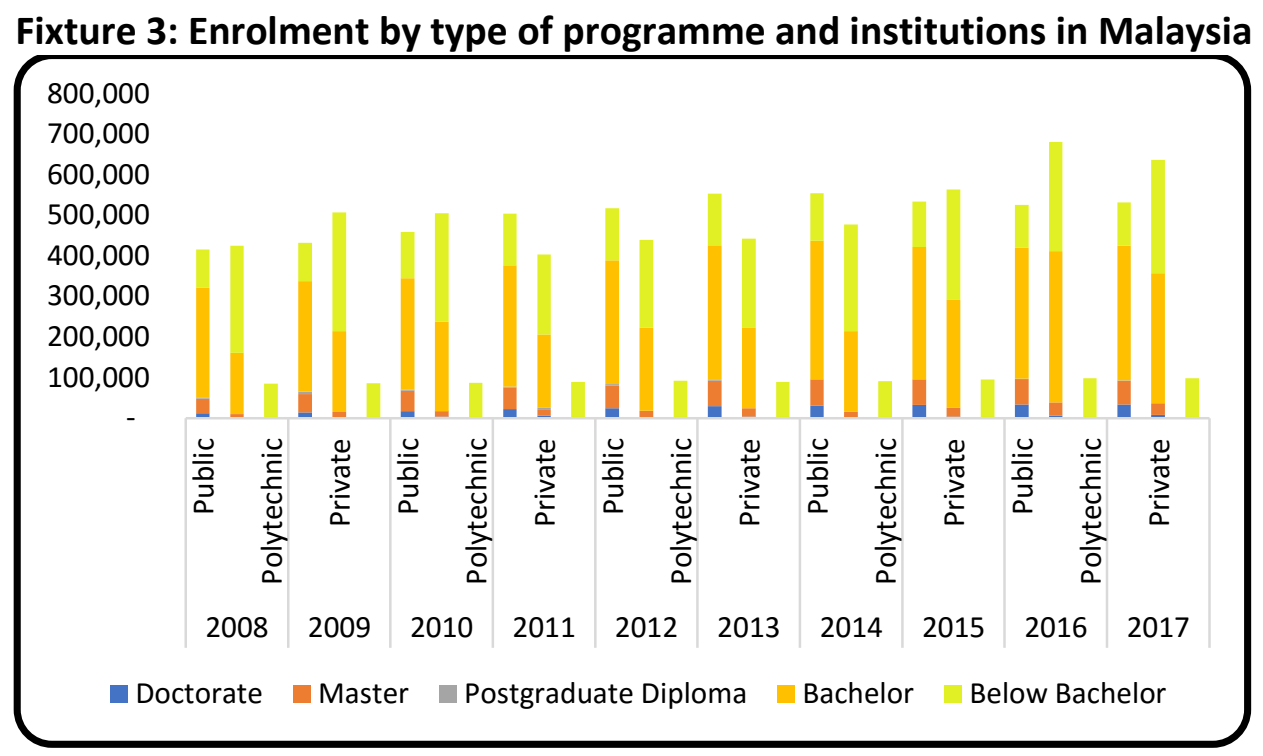

Source: Ministry of Higher Education of Malaysia (2008-2017)

Fixture 3 shows the enrolment of students in higher education in Malaysia from 2008 to 2017. In general, the number of enrolments were in increasing trend throughout the years for public universities, private institutions, and polytechnic. Public universities had higher number of enrolments for bachelor degree programmes from 2009 to 2015 across all institutions in Malaysia. However, the number of students enrolled for bachelor programmes have shifted from public universities to private institutions. This is due to limited number of admissions available in the public universities as compared to the private institutions, and the increment the number of private institutions in the country.

\section{Discussion}

This section discusses the current practices and sources of education financing in Malaysia. Additionally, the section also discusses among the best practices around the world relating to education financing in respective countries.

\section{Current Practices of Higher Education Financing in Malaysia}

In the past, students rely heavily on government scholarships in order to further their studies in tertiary level or higher especially in the foreign university abroad. However, this model cannot sustain for long-term because of the nature of scholarships which will limit the number of recipients which contradict with the nation aspirations to produce more university graduates. Therefore, in 1997, the government of Malaysia, via an act of parliament, formed the National Higher Educational Fund Corporation (NHEFC), also known as Perbadanan Tabung Pendidikan Tinggi Nasional (PTPTN) as a semi-autonomous agency under the Ministry of Higher Education (MOHE). PTPTN was tasked with the accountability of distributing and administering educational financing to help poorer students finance their higher education in terms of tuition fees and living costs. The PTPTN financing is made available to students pursing studies at all local public and 
private universities, as well as polytechnics. Students pursuing their diploma, bachelor's degree, master, doctorate or professional courses are eligible to apply for these financing scheme (Ong et al., 2016).

The scheme looks promising at first but due to high number of non-payment, the operation of PTPTN seems unsustainable in the long-run. Ong et al. (2016) pointed that the amount of government grants has almost doubled from RM915 million in 2011 to RM1.715 billion in 2015, suggesting an over-reliance on government aid to cover its cost of operations. Besides PTPTN, eligible students may opt for financing or scholarships from Majlis Amanah Rakyat (MARA), Koperasi Jayadiri Malaysia Berhad (KOJADI), Maju Institute of Educational Development (MIED), Yayasan Bank Rakyat, and various commercial banks. Due to the nature of inclusiveness and uncompetitive rate, these sources are considered minority and seldom be used by the major parts of the public.

\section{Practices around the Globe: Higher Education Financing}

Table 1 below summarises some practices regarding higher education financing all around the world.

Table 1: Practices around the Globe

$\begin{array}{ll}\text { Practices } & \text { Authors }\end{array}$

\section{Australia and England}

Universities in England and Australia operate in the public sector with tuition charges set by government. Upon enrolment, domestic students choose between

Barr et al. (2017) paying tuition upfront or deferring their obligation through an Income Contingent Loans (ICL) system. The vast majority (85 per cent in Australia, 90 per cent in England) choose to defer, and a student's debt is recorded and linked to his/her unique social security/tax file number. When a borrower starts working, employers withhold loan repayments based on the borrower's current income in the same way that they withhold social security payments and income tax.

Outstanding debt is recorded and reconciled within a government agency, which can be the tax authorities or a separate loans administration, such as the UK Student Loans Company. incomes exceed a certain amount, GBP 21,000 per year (USD 26,000) in Britain and AUD about 57,000 (USD 42,000) per year in Australia. Above these thresholds loan repayments are an increasing proportion of income, but cannot exceed 9 and 8 per cent of incomes, respectively in Britain and Australia. When the loans has been fully repaid, employers are informed and repayment collections cease; the median duration is about 8 years in Australia and about 27 years in Britain (where average debts are much larger), although the variance is considerable; in Britain all outstanding loans are forgiven after 30 years, but there is no maximum repayment period in Australia. Both systems charge interest, and both include an element of interest subsidies, 


\section{Korea}

Universities with state subsidies are divided into three types by their purpose of use: operating expenses of public universities and colleges, student scholarships, and programmes for specific purposes. The Ministry of Education of Korea has

Kim and Park (2018) been supporting universities financially by unit of programme teams. It means that the Korean government has been using a public offering method to induce change and innovation for government-centralised universities. The government has used an 'apply-evaluate-select' process to reinforce evaluation and competing structures and this support has also been used for restructuring universities. Policies in those universities that rely on state subsidies programmes at higher levels continue to change along with the index of evaluation from the government. This means that a state subsidies programme may not only serve as financial support, but also as a key factor for school management. The current government also uses the programmes to re-establish a duty and role for the university that embraces industry demand and rapid social change.

\section{Japan}

The central government of Japan allocated over $90 \%$ of national universities' funding prior to March 2004 when all public universities became national university corporations. Similarly, as their mission is expected to be more responsive and relevant to the demands of local economic development, community and industry, more than half of local public universities' revenue comes from local authorities. In contrast, although the central government has provided some financial support to private universities since 1973, the proportion of public subsidies makes up of less than $20 \%$ of their total revenue. Furthermore, clear differences in funding mechanisms are identified not only between the three sectors, but also within each sector. The available funding varies even within the same sector of universities depending on their history, traditions, academic and social prestige, the size of student enrolment, missions, national policies, and so forth. From the perspective of student service, Japan has developed various programmes for different types of students. Among different public or private agencies and organizations which are involved in providing student support, a special mention should be made of the Japan Student Services Organization (JASSO). Currently, it mainly provides four programmes to prepare an environment suitable for both Japanese and international students to study in either Japanese or foreign universities. JASSO provides Scholarship Loan Programmes in the form of Category 1 Loans (interest-free) and Category 2 (interest bearing) for Japanese students who study in all types of higher education institutions. 


\section{India}

Due to the size and complexity of higher education in India, there are multiple strategies in addressing the financial partnerships and trends. With a recent colonial history, India struggles with the pressures of tradition on one hand and outside influence on the other. India use the three-tier system of higher education that has evolved over the two decades and can be categorised as the following:

Research-focused Institutions.

The first tier is involved of the highly selective elite research universities. These to be funded by the government, endowments from industry, and Industry sponsored research.

\section{Career-focused Institutions}

The second tier is comprised of the comprehensive universities and specialised institutions. These institutions deliver economic value by offering industry-aligned courses that focus on student learning outcomes and produce industry-ready graduates and are to be funded by private philanthropic endowments, alumni networks and government aid for scholarships.

\section{Foundation Institutions}

The third tier is encompassed of the highly accessible and high-quality colleges. These institutions impart skill-based training such as technical and vocational skills to enable employability at grassroots and thereby serve economic needs and are to be funded by the government for infrastructure and scholarships along with government/industrial funding for community-based research.

\section{Middle-east and North Africa (MENA)}

Higher education system in Middle-east are quite different from one country to another. In Tunisia, Morocco, Syria and Egypt, the majority enrolment of higher education is in the public universities. On the other hand, students in Lebanon mostly enrolled in private universities due to historical establishment of private institutions years earlier. Meanwhile, it is quite balance between public and private university enrolments for students in Jordan.

In his study, El-Araby identified Morocco, Syria, Jordan and Egypt as lower-middleincome (LMI) countries according to World Bank. As for Tunisia and Lebanon, it was classified as upper-middle-income (UMI) countries. The study concluded that the government of Syria, Tunisia and Morocco allocated above the average spending on education as per GDP i.e. 4.5\%. However, Egypt, Jordan and Lebanon spent less than the average with Lebanon recorded the lowest allocation of 3.1\% only. What these findings suggest is that Lebanon, Jordan, and Egypt do not 
allocate adequate resources to higher education, compared to the other Arab countries and the LMI countries. Further findings of the study found that the students in higher education rarely come from the lowest income brackets. Poor students are more likely to drop out of school: children from the poorest population quintile in Egypt represent $25 \%$ of students in primary school, $14 \%$ of those in secondary school, and only $4 \%$ of those in higher education. Similar observations can be made with respect to the other Arab countries. In Jordan's higher education institutions, the enrolments of students from the richest quintile are three times those from the poorest quintile. Similarly, in Tunisia, students from higher-income households are over-represented in higher education institutions compared to the population as a whole.

\section{Conclusion}

This study presents an overview of the financing mechanisms of Malaysian higher education, and outlines changes occurring in these mechanisms since the early 2000s. Compared to previous studies, the originality of the study can be summarised as follows.

Fundamentally, the government has big responsibilities related to higher education. From national level point of view, there should be various alternatives for obtaining higher education financing for the people. The government should relax financial regulations, provide tax relief, and award state subsidies based on student enrolment. The government has provided various kinds of support for higher education. However, this is not enough compared to other sectors or other countries. As for improving PTPTN scheme. Some measurements have been made by the institution. Scheduled Salary Deductions (SSDs) has been implemented for borrowers with salary above RM2, 000 per month with the rate as low as $2 \%$ of their basic salary. However, the implementation and monitoring are still considered lacking because the number of non-payment cases are high. In order to increase the repayment rates, repayment should be automatically deducted from the salaries of those graduates who are already eligible to service their loans (Ong et al., 2016). This structure is already in place for Employees Provident Fund (EPF) and Social Security Organisation (SOCSO) contributions. It is also a common practice in countries like United Kingdom and Australia where automatic deduction amounts are adjusted according to the amount of salary earned as discussed in the previous section. Therefore, the number of nonpayment accounts can be reduced tremendously.

Additionally, strategies like funding reforms, diversified funding, cost-sharing mechanisms, and entrepreneurship programmes have also been used to raise necessary funds for higher learning institutions. Although, in practice public universities in Malaysia depend on the Federal Government for the bulk of its financial resources, some efforts are being made by the universities to generate income from alternative sources. These alternative sources of funding include income from investments, campus services, alumni fundraising and royalty income from commercialised research and patents. The Islamic concept of waqf also can be explored as potential alternative. Aziz et al. (2013); Kadir, Johari, \& Hussin (2018); Anghelache, Anghel, Dumitrescu, Avram (2018) suggested that waqf instrument can be utilised for the 
education financing especially for higher education. This is due to the fact that education is very crucial for the development of human capital and important social well-being for individual, society, and nation as a whole. The greatness of the Islamic waqf institution was so impressive and effective that it was emulated by the West which rebranded waqf in the form of foundations, trust or endowment. Oxford University and Cambridge in United Kingdom as well as Harvard and Stanford in United States are among universities which are founded on endowments with a wellestablished fund. Harvard University, for example, is reported to be one of the richest universities with endowment assets worth more than US\$30 billion (Mujani et al., 2016). We should re-look into this matter and try to empower back the greatness of waqf as a tool of funding for higher education either at the university level, or perhaps by the corporate sector.

With regards to financial technology (fintech), a few financial services startup already have provided platforms for higher education financing such as Prodigy Finance, a London-based company who specialises in financing provider for international post-graduates in top-100 international ranked universities. From Malaysian perspective, there is a platform called Skolafund who focuses on the underprivileged higher education students across the country. Moving forward, perhaps there will be more providers like this who can offer to masses as an alternative of higher education funding or financing.

\section{Corresponding Author}

Mohd Faizal Basri, Faculty of Management and Economics, Universiti Pendidikan Sultan Idris, Malaysia.

Email: mfaizal.basri@fpe.upsi.edu.my

\section{Acknowledgement}

This research is funded by Universiti Pendidikan Sultan Idris Research Grant (2017-0318-107-01)

\section{References}

Jabbar, A. N., \& Selvaratnam, D. P. (2017). Analysis of the determinants of education expenditures in Malaysia. Journal of International Business, Economics and Entrepreneurship (JIBE), 2(1), 1-10.

Aziz, M. R. A., Johari, F., \& Yusof, M. A. (2013). Cash waqf models for financing in education. In The 5th Islamic Economic System Conference (iECONS2013) (pp. 835-842).

Barr, N. (1993). Alternative Funding Resources for Higher Education. The Economic Journal, 103(418), 718.

Barr, N., Chapman, B., Dearden, L., \& Dynarski, S. (2017). Getting student financing right in the US: lessons from Australia and England. Centre for Global Higher Education.

Bray, M., \& Lillis, K. (Eds.). (2016). Community Financing of Education: Issues \& Policy Implications in Less Developed Countries (Vol. 5). Elsevier.

Bernama. (2017). PTPTN not facing financial difficulty, says Idris. Bernama. Kuala Lumpur. Retrieved from https://www.nst.com.my/news/2017/02/211441/ptptn-not-facingfinancial-difficulty-says-idris 
Chapman, B., \& Sinning, M. (2014). Student loan reforms for German higher education: financing tuition fees. Education Economics, 22(6), 569-588.

Chattopadhyay, S. (2007). Exploring alternative sources of financing higher education. Economic and Political Weekly, 4251-4259.

Da, W. C. (2012). The Changing Gender Disparity in Malaysian Higher Education: Where are the boys?.

El-Araby, A. (2011). A comparative assessment of higher education financing in six Arab countries. Prospects, 41(1), 9-21.

Gibbons, A. (2016). The countries offering students free (or somewhat affordable) university education. The Independent. London. Retrieved from

http://www.independent.co.uk/student/studyabroad/

free-university-education-courses-study-abroad-brexit-erasmus-students-germanycopenhagenfrance-a7457576.html

Heller, D. E., \& Callender, C. (2013). Student Financing of Higher Education: A Comparative Perspective. Routledge.

Huang, F. (2018). Higher education financing in Japan: Trends and challenges. International Journal of Educational Development, 58, 106-115.

Kim, B., \& Park, N. (2018). Lessons learned from financing universal higher education in Korea. International Journal of Educational Development, 58, 116-127.

Ministry of Higher Education Malaysia, Perangkaan Pengajian Tinggi Malaysia (2008-2017). Kementerian Pendidikan Tinggi Malaysia. Kuala Lumpur.

Mujani, W. K., Taib, M. S. M., \& Rifin, M. K. I. (2016). Waqf higher education in Malaysia. In 2016 International Conference on Education, E-learning and Management Technology. Atlantis Press.

Mustafa, Z. (2017). How much would it cost to pursue higher education in Malaysia? New Straits Times. Kuala Lumpur. Retrieved from

https://www.nst.com.my/news/2017/03/223461/how-much-would-it-costpursue-highereducation-malaysia

Ong, K. M., Yong, J., Chew, K. Y., \& Ng, D. (2016). The sustainability of the PTPTN loan scheme. Penang Institute, Malaysia.

Phoong, S. Y., Phoong, S. W., \& Tan, X. J. (2018). A Mediation Analysis on Level of Education and Economic Growth. The Journal of Social Sciences Research, 417-422.

PTPTN website. (n.d.). Official Portal of Perbadanan Tabung Pendidikan Tinggi Nasional. Retrieved August 2017, from http://www.ptptn.gov.my/web/guest/anjung

Roberts, K. J. (2018). Community engagement in Indian higher education: financial and partnership trends. International Journal of Educational Development, 58, 95-105.

Solemon, B., Ariffin, I., Din, M. M., \& Anwar, R. M. (2013). A review of the uses of crowdsourcing in higher education. International Journal of Asian Social Science, 3(9), 2066-2073.

Unesco Institute of Statistics website (n.d.). Official Portal of UIS, UNESCO. Retrieved March 2018, from http://uis.unesco.org/country/MY 
Kadir, M. R. A., Johari, N. I. S., \& Hussin, N. (2018). Information Needs and Information Seeking Behaviour: A Case Study on Students in Private University Library. International Journal of Academic Research in Progressive Education and Development, 7(3), 226-235.

Anghelache, C., Anghel, M. G., Dumitrescu, D., Avram, D. (2018). Romania's Strategy in the Field of Research and Innovation, in the Context of the European Union, International Journal of Academic Research in Accounting, Finance and Management Sciences 8 (2): 95-101. 